\title{
Nutritional value, chemical composition and antioxidant activity of three Tuber species from China
}

\author{
Xiangyuan Yan, Yanwei Wang, Xiaoyu Sang and Li Fan*
}

\begin{abstract}
Nutritional value, chemical composition and antioxidant activity of the traditional edible truffles Tuber latisporum, $T$. subglobosum and T. pseudohimalayense, from China were evaluated. Powder formulations of the three truffles revealed the presence of essential nutrients, such as proteins, carbohydrates and unsaturated fatty acids, and T. latisporum presented the highest contents of total sugar $(50.10 \mathrm{~g} / 100 \mathrm{~g})$ and monounsaturated fatty acids $(265.19 \mathrm{mg} / 100 \mathrm{~g}$ $\mathrm{dw}$ ); T. pseudohimalayense showed the highest content of polyunsaturated fatty acids ( $367.98 \mathrm{mg} / 100 \mathrm{~g} \mathrm{dw}$ ). They all presented a low fat content but high contents of proteins and unsaturated fatty acid, which is beneficial to human health. The methanol extract from T. pseudohimalayense showed a high radicals scavenging activity and the highest content of total phenols ( $735.01 \mathrm{mg} / 100 \mathrm{~g} \mathrm{dw})$; T. subglobosum presented the highest content of flavonoids $(1355.43 \mathrm{mg} / 100 \mathrm{~g} \mathrm{dw})$. All these extracts could be used as potential antioxidant sources to prevent diseases related to oxidative damage.
\end{abstract}

Keywords: Truffle, Nutrients, Bioactive compounds, DPPH, Reduce power

\section{Introduction}

Mushrooms are a popular food in the world and they have become very attractive due to their low calories, fats, and essential fatty acids (FA), and rich vegetable proteins, vitamins and minerals (Wang and Marcone 2011; Hamza et al. 2016). Truffles, a group of hypogenous mushroom belonging to the Ascomycota, were particularly appreciated for their unique aroma, great economic value and potential health benefits (Hall et al. 2003; Beara et al. 2014). In fact, truffles were rich in unsaturated fatty acids (UFA), some kind of free sugars that are good for human health, and therapeutic compounds with antiinflammatory, antioxidant, antimicrobial, anti-mutagenic and anti-carcinogenic properties (Bokhary and Sarwat 1993; Carneiro et al. 2013; Culleré et al. 2010; Dundar et al. 2012; Gao et al. 2001a, b; Murcia et al. 2002; Saltarelli et al. 2008; Sawaya et al. 1985; Stojković et al. 2013).

*Correspondence: lifan1966@hotmail.com College of Life Science, Capital Normal University, Beijing 100048, People's Republic of China
A radical is any molecule or atom with one or more unpaired electrons, normally generated in many metabolic pathways in the human body. Some of them can exist in a free form and subsequently oxidize biological molecules such as lipids, DNA, carbohydrates and proteins, resulting in the damage to these molecules and the dysfuction of related tissue components (Kehrer 1993; Dubost et al. 2007). These free radicals have come to occupy a central role in a wide variety of diseases, such as atherosclerosis, cancer, rheumatoid arthritis and degenerative processes associated with aging (Lee et al. 2004). Some recent reports had shown the truffles, have the ability to scavenge free radicals because they contain various polyphenolic/phenolics, flavonoids or sterols compounds (Beara et al. 2014; Tang et al. 2012; Stojković et al. 2013; Villares et al. 2012), which are recognized as an antioxidant due to their ability to scavenge free radicals by acting as reducing agents, hydrogen donating antioxidants and singlet oxygen quenchers (Barros et al. 2007).

The three truffle species in this study, Tuber latisporum, T. subglobosum and T. pseudohimalayense, are also traditional edible mushrooms with a great production 
in China. Our aim was to increase the knowledge about their chemical composition and nutritional properties, with regard to the contents of energy, carbohydrate, protein, fat, ash, free sugar and fatty acid; to investigate the antioxidant activity of these truffles, including scavenging ability for DPPH and hydroxyl radicals, reduce power, chelating effect on ferrous ion. This is the first report on the chemical constituents and antioxidant activities of the three Chinese truffles. Gas chromatography-mass spectrometer (GC-MS) and high-performance liquid chromatography (HPLC) techniques were applied to evaluate composition analysis, the antioxidant potential was determined using various assays.

\section{Materials and methods Truffle samples}

Fresh ascocarp samples of T. latisporum, T. subglobosum and T. pseudohimalayense were collected from local markets in Yunnan province of China and were authenticated by Dr. Li Fan (College of Life Science, Capital Normal University, PR China). All the truffles were identically selected in terms of shape, size, colour, and ripening stage. After collection and taxonomic identification, fresh truffles were selected and washed to remove contaminants, then freeze-dried (Wizard 2.0, VirTis, USA) at $-45^{\circ} \mathrm{C}$. The lyophilized truffle samples were ground into fine powder (40 mesh) with a Mixer Mill (Retsch, Haan, Germany). The lyophilized truffle samples were stored in the dark at $4{ }^{\circ} \mathrm{C}$ until analysis.

\section{Standards and reagents}

Acetonitrile 99.9\%, $n$-hexane $95 \%$ and methanol $99.9 \%$ were purchased from Fisher Scientific (Shanghai, China). The fatty acids methyl ester (FAME) reference standard mixture 37 (standard 47885-U) was purchased from Sigma (St. Louis, MO, USA). Sugars standards [glucose, sorbitol and $\mathrm{D}(+)$-trehalose and myo-inositol], phenolic standards (gallic, 4-hydroxybenzoic, 3,4-dihydroxybenzaldehyde, homogentisic, $p$-coumaric and $o$-coumaric acids) were purchased from Sigma (St. Louis, MO, USA) or Sigma-Aldrich Chem (shanghai, China). 1,1-Diphenyl2-picryl-hydrazyl (DPPH), BHT, 3-(2-pyridyl)-5,6-bis (4-phenyl-sulfonic acid)-1,2,4-triazine (ferrozine), rutin and ascorbic acid were purchased from Sigma Chemical Co. BSTFA + TMCS (99:1) was purchased from Supelco. Folin-Ciocalteu's phenol reagent was purchased from Beijing Solarbio reagent company (Beijing, China). Ferrous chloride, sodium salicylate, ferrous sulphate, hydrogen peroxide, potassium ferricyanide, trichloroacetic acid, disodium phosphate, sodium dihydrogen phosphate, ferric chloride, sodium carbonate, sodium hydroxide, aluminium nitrate, sodium nitrite, petroleum ether $\left(60-90{ }^{\circ} \mathrm{C}\right)$, ethanol and methanol were all purchased from Beijing chemical plant (Beijing, China). All chemicals were of analytical grade. Water was treated in a Milli-Q water purification system (TGI Pure Water Systems, USA).

\section{Analysis of chemical composition \\ Nutritional value}

The lyophilized truffle samples were analyzed for proteins, fat, carbohydrates and ash, using the AOAC (1995) procedures. The crude protein content $(\mathrm{N} \times 4.38)$ of the samples was estimated by the macro-Kjeldahl method; the crude fat was determined by extracting a known weight of powdered sample with petroleum ether, using a Soxhlet apparatus; the ash content was determined by incineration at $600 \pm 15{ }^{\circ} \mathrm{C}$. Total carbohydrates were calculated by difference. Energy was calculated according to the following equation: energy $(\mathrm{kcal})=4 \times(\mathrm{g}$ proteins $+\mathrm{g}$ carbohydrates $)+9 \times(\mathrm{g}$ fat $)$.

\section{Sugars}

The lyophilized truffle samples $(2 \mathrm{~g})$ were spiked with the Internal Standard (IS, raffinose, $5 \mathrm{mg} / \mathrm{mL}$ ), and were extracted with $120 \mathrm{~mL}$ of $80 \%$ aqueous ethanol at $80{ }^{\circ} \mathrm{C}$ for $1 \mathrm{~h} 30 \mathrm{~min}$. The resulting suspension was filtered and concentrated using a rotary evaporator (Laborota 4003, Heidolph WB, Germany) and defatted three times with $20 \mathrm{~mL}$ of petroleum ether, successively. After concentration, the residues were dissolved in water to a final volume of $1000 \mathrm{~mL}$.

Sugars were determined after a silanization procedure performed. $200 \mu \mathrm{L}$ dilute solution was evaporated to dryness over $\mathrm{N}_{2}$ then $100 \mu \mathrm{L}$ BSTFA + TMCS (99:1, $\mathrm{v} / \mathrm{v}$ ) and $20 \mu \mathrm{L}$ pyridine were added, reacting at $70{ }^{\circ} \mathrm{C}$ for $2 \mathrm{~h}$. After $580 \mu \mathrm{L}$ dichloromethane added, the sample was recovered in a vial with Teflon cap, and before injection the sample was filtered with $0.2 \mu \mathrm{m}$ Nylon filter from Millipore.

The analysis was performed using GC-MS (Thermo Finnigan trace DSQ II) equipped with a fused silica HP-5MS capillary column $(30 \mathrm{~m} \times 0.25 \mathrm{~mm}$ ID $\times 0.25 \mu \mathrm{m} \mathrm{df}) .1 \mu \mathrm{L}$ of sample was injected in a split/ splitless injector set at $250{ }^{\circ} \mathrm{C}$. The GC was setup with helium as a carrier gas at a constant flow of $1.0 \mathrm{~mL} / \mathrm{min}$. The column temperature program was: $50{ }^{\circ} \mathrm{C}(2 \mathrm{~min})$; to $120{ }^{\circ} \mathrm{C}(5 \mathrm{~min})$ at $15{ }^{\circ} \mathrm{C} / \mathrm{min}$; to $290{ }^{\circ} \mathrm{C}(10 \mathrm{~min})$ at $5{ }^{\circ} \mathrm{C} /$ $\mathrm{min}$. The mass spectrometer was used in electron impact mode, with the electron energy at $70 \mathrm{eV}$, ion source temperature at $290{ }^{\circ} \mathrm{C}$, transfer line temperature was $290{ }^{\circ} \mathrm{C}$, scan range $\mathrm{m} / \mathrm{z}$ : 50-550 amu, data acquisition scan mode for full scan.

Sugars' identification was made by comparing the relative retention times of sample peaks with standards. Quantification was based on the MS signal response of 
each standard, using the IS method and by using calibration curves obtained from commercial standards of each compound. The results were expressed in $\mathrm{g}$ per $100 \mathrm{~g}$ of dry weight.

\section{Fatty acids}

Fatty acids were determined after a transesterification procedure performed with the oil obtained by soxhlet extraction (extraction ratio: T. latisporum 2.40\%; T. subglobosum 2.23\%; T. pseudohimalayense $2.55 \%$ ): fatty acids $(2 \mathrm{mg}$ ) were methylated with $6 \mathrm{~mL}$ of $0.6 \mathrm{~mol} / \mathrm{L} \mathrm{NaOH}$ methanol solution: $n$-hexane 2:1 (v:v) with vortexing for $3 \mathrm{~min}$. After $20 \mathrm{~min}$ in a bath at $30{ }^{\circ} \mathrm{C}, 3 \mathrm{~mL}$ of deionized water was added, to obtain phase separation; the upper phase was recovered in a vial, and before injection the sample was filtered with $0.2 \mu \mathrm{m}$ Nylon filter from Millipore. The analysis was performed using GC-MS equipped with a fused silica HP-5MS capillary column $(30 \mathrm{~m} \times 0.25 \mathrm{~mm} \mathrm{ID} \times 0.25 \mu \mathrm{m} \mathrm{df})$. The column temperature program was: $45^{\circ} \mathrm{C}(1 \mathrm{~min})$; to $175{ }^{\circ} \mathrm{C}(2 \mathrm{~min})$ at $10{ }^{\circ} \mathrm{C} / \mathrm{min}$; to $210{ }^{\circ} \mathrm{C}(5 \mathrm{~min})$ at $1{ }^{\circ} \mathrm{C} / \mathrm{min}$; to $280{ }^{\circ} \mathrm{C}$ (1 min) at $5{ }^{\circ} \mathrm{C} / \mathrm{min} .1 \mu \mathrm{L}$ of sample was injected.

\section{Analysis of chemical composition in bioactive compounds General}

The sample (15 g) was stirred with methanol $(300 \mathrm{~mL})$, sonicated for $30 \mathrm{~min}$ and incubated at $35^{\circ} \mathrm{C}$ for $1 \mathrm{~h}$. Then, the methanol extract (ME) was centrifuged at $5000 \mathrm{~g}$ for $15 \mathrm{~min}$ at $35^{\circ} \mathrm{C}$. The residue was then re-extracted under the same conditions. The combined extracts were filtered through Whatman No. 1 filter paper; the filtrate was collected and evaporated using a rotary evaporator, weighed and re-dissolved in methanol at $50 \mathrm{mg} / \mathrm{mL}$ (stock solution), and stored in the dark at $4{ }^{\circ} \mathrm{C}$ for further use. Successive dilutions were made from the stock solution and submitted to different in vitro assays to evaluate the content of active compounds and antioxidant activity of the samples.

\section{Total phenols}

$1 \mathrm{~mL} \mathrm{ME} \mathrm{(3} \mathrm{mg/mL)} \mathrm{was} \mathrm{mixed} \mathrm{with} 1 \mathrm{~mL}$ of Folin-Ciocalteu's phenol reagent; after $3 \mathrm{~min}, \mathrm{Na}_{2} \mathrm{CO}_{3}(35 \%, 1 \mathrm{~mL})$ was added, and then distilled water was added making the reaction system reach $10 \mathrm{~mL}$. The reaction mixture was mixed thoroughly and allowed to stand for $90 \mathrm{~min}$ at room temperature in the dark. Absorbance of all the sample solutions against a blank was measured at $725 \mathrm{~nm}$ using the spectrophotometer (Lambda 35, Perkin Elmer Co. Ltd., USA). Total phenolic contents were expressed as mg gallic acid (Sigma) equivalents, GAE/100 g of extract. Calibration curve was constructed with different concentrations of Gallic acid $(1-12 \mu \mathrm{g} / \mathrm{mL})$ as the standard. The assays were carried out in triplicate; total phenolic contents were mean values \pm standard deviations.

\section{Total flavonoids}

Total flavonoids of ME were measured by the method of Guo et al. (2011). A calibration curve was constructed with different concentrations of rutin $(0.01-0.1 \mathrm{mg} / \mathrm{mL})$ as the standard. The assays were carried out in triplicate; total flavonoid contents were expressed on an extract weight basis as $\mathrm{mg} / \mathrm{g}$ rutin equivalents, rutin $\mathrm{mg} / 100 \mathrm{~g}$ of extract.

\section{VC}

Ascorbic acid was determined according to the method of Klein and Perry (1982) with slight modification in the content of metaphosphoric acid in extraction. $100 \mathrm{mg}$ ME was extracted with $10 \mathrm{~mL}$ of $1 \%$ metaphosphoric acid for $45 \mathrm{~min}$ at room temperature and filtered through Whatman No. 4 filter paper. The filtrate was mixed with 2,6-dichlorophenolindophenol (1v:9v) and the absorbance was measured at $515 \mathrm{~nm}$ against a blank within $30 \mathrm{~min}$. A calibration curve was constructed with different concentrations of authentic L-ascorbic acid (0.020$0.12 \mathrm{mg} / \mathrm{mL}$ ) as the standard. The assays were carried out in triplicate; the results were mean values \pm standard deviations and expressed in $\mathrm{g} / 100 \mathrm{~g}$ of dry weight.

\section{$\beta$-Carotene and lycopene}

$\beta$-Carotene and lycopene were determined by the following process (Barros et al. 2007). $100 \mathrm{mg} \mathrm{ME}$ was vigorously shaken with $10 \mathrm{~mL}$ of acetone-hexane mixture (4:6) for $1 \mathrm{~min}$. The absorbance of the filtrate was measured at 453, 505 and $663 \mathrm{~nm}$. Contents of $\beta$-carotene and lycopene were calculated according to the following equations: lycopene $(\mathrm{mg} / 100 \mathrm{~mL})=-0.0458 \mathrm{~A}_{663}+0.37$ $2 \mathrm{~A}_{505}-0.0806 \mathrm{~A}_{453} ; \beta$-carotene $(\mathrm{mg} / 100 \mathrm{~mL})=0.216 \mathrm{~A}_{663}$ $-0.304 \mathrm{~A}_{505}+0.452 \mathrm{~A}_{453}$. The assays were carried out in triplicate; the results were mean values \pm standard deviations and expressed in $\mathrm{mg} / 100 \mathrm{~g}$ of dry weight.

\section{Phenolic compounds}

Phenolic compounds were analyzed using a HewlettPackard 1200 chromatograph (Agilent Technologies) with a quaternary pump and a diode array detector (DAD) coupled to an HP Chem Station (rev. A.05.04) data-processing station. The solvents used were: (A) $0.1 \%$ acetic acid in water, (B) acetonitrile. The elution gradient established was $5 \%$ B to $5 \%$ B over 5 min, 5-33\% B over $15 \mathrm{~min}, 33-80 \%$ B over $10 \mathrm{~min}, 80-100 \%$ B over $5 \mathrm{~min}$, isocratic $100 \%$ B for $5 \mathrm{~min}$, and re-equilibration of the column, using a flow rate of $1 \mathrm{~mL} / \mathrm{min}$. Double online detection was carried out in the DAD using 280 and $370 \mathrm{~nm}$ as preferred wavelengths. The phenolic compounds were characterized according to their UV retention times, and comparison with authentic standards when available. For quantitative analysis, calibration curves were prepared 
from different standard compounds $\left(r^{2}>0.999\right)$. The assays were carried out in triplicate; the results were expressed in $\mathrm{mg} / 100 \mathrm{~g}$ of dry weight.

\section{Evaluation of antioxidant activity Ferrous ion-chelating assay}

Ferrous ion-chelating activities of ME were evaluated by the following process (Guo et al. 2011). An aliquot of each sample $(1 \mathrm{~mL})$, with different concentrations, was mixed with $\mathrm{FeCl}_{2}(2.0 \mathrm{mM}, 0.1 \mathrm{~mL})$ and methanol $(3.7 \mathrm{~mL})$. The reaction was initiated by adding ferrozine $\left(5.0 \mathrm{mM}, 0.2 \mathrm{~mL}\right.$ ), and incubated at $35^{\circ} \mathrm{C}$ for $20 \mathrm{~min}$. The absorbance of the mixture was determined at $562 \mathrm{~nm}$.

\section{Ferricyanide/Prussian blue assay}

Ferrous ion-chelating activities of ME were evaluated by the method of Guo et al. (2011). Solutions of the ME at different concentrations $(0.2 \mathrm{~mL})$ were mixed with sodium phosphate buffer ( $200 \mathrm{mmol} / \mathrm{L}, \mathrm{pH} 6.6,0.5 \mathrm{~mL})$ and potassium ferricyanide $(1 \% \mathrm{w} / \mathrm{v}, 0.5 \mathrm{~mL})$. The mixture was incubated at $50{ }^{\circ} \mathrm{C}$ for $20 \mathrm{~min}$, and trichloroacetic acid $(10 \% \mathrm{w} / \mathrm{v}, 0.2 \mathrm{~mL})$ was added, followed by centrifugation at $3000 \mathrm{~g}$ for $10 \mathrm{~min}$. The supernatant $(0.5 \mathrm{~mL})$ was mixed with deionized water $(0.5 \mathrm{~mL})$ and ferric chloride $(0.1 \% \mathrm{w} / \mathrm{v}, 0.1 \mathrm{~mL})$; then the absorbance was measured at $700 \mathrm{~nm}$.

\section{DPPH scavenging activity assay}

Aliquots $(0.1 \mathrm{~mL})$ of various concentrations $(0-30 \mathrm{mg} /$ $\mathrm{mL})$ of $\mathrm{ME}$ were mixed with $0.9 \mathrm{~mL}(25 \mu \mathrm{g} / \mathrm{mL})$ of a $\mathrm{MeOH}$ solution of DPPH. The mixture was shaken and left in the dark for $30 \mathrm{~min}$ (Guo et al. 2011). The absorbance was measured with a spectrophotometer at $517 \mathrm{~nm}$ against a blank.

\section{Hydroxyl radical-scavenging assay}

Hydroxyl radical-scavenging activities of ME were determined according to the method described by Guo et al. (2011). Sodium salicylate (20 mM, $0.3 \mathrm{~mL}), \mathrm{FeSO}_{4}$ (1.5 mM, 1.0 mL), various concentrations of sample solution $(1.0 \mathrm{~mL})$ and $\mathrm{H}_{2} \mathrm{O}_{2}(6.0 \mathrm{mM}, 0.7 \mathrm{~mL})$ were mixed immediately and left at $37^{\circ} \mathrm{C}$ for $1 \mathrm{~h}$. The absorbance of the mixture was recorded at $510 \mathrm{~nm}$.

\section{Statistical analysis}

All the assays were carried out in triplicate. The results are expressed as mean values \pm SD (standard deviations). Statistical analyses were performed using a one-way analysis of variance ANOVA test and the significance of the difference between means was determined by Duncan's multiple range test. Differences at $\mathrm{p}<0.05$ were considered statistically significant. This treatment was carried out using SPSS v. 16.0 program.

\section{Results}

Chemical composition in nutritional compounds

The results of the macronutrients, estimated energetic value and individual sugars of the studied lyophilized truffle samples are shown in Table 1. Carbohydrates were the most abundant macronutrients, followed by proteins; fat and ash contents were low. Their carbohydrate contents were close to each other, respectively $74.63 \%$ in T. latisporum, $78.68 \%$ in T. subglobosum and $74.40 \%$ in T. pseudohimalayense; the contents of protein in white truffle T. latisporum (14.64\%) and red truffle T. pseudohimalayense (14.28\%) were higher than that of pale yellow truffle T. subglobosum (10.96\%); the fat contents in all three truffles can be as low as $2.23-2.55 \%$.

The analytical results on free sugars (Table 1) indicated that sorbitol, trehalose, glucose and inositol could be detected in our three truffle samples, and sorbitol and trehalose were the main free sugars; the contents of total sugar ranged from 23.89 to $50.10 \mathrm{~g} / 100 \mathrm{~g}$ $\mathrm{dw}$. The main free sugars found in T. latisporum were sorbitol (33.82 g/100 g dw) and trehalose (13.84 g/100 g $\mathrm{dw})$, followed by glucose $(1.25 \mathrm{~g} / 100 \mathrm{~g} \mathrm{dw})$ and inositol (1.18 g/100 $\mathrm{g} \mathrm{dw})$; in T. subglobosum dominant were sorbitol (22.65 g/100 $\mathrm{g} \mathrm{dw}$ ) and trehalose (4.41 g/100 g $\mathrm{dw})$, followed by inositol $(2.00 \mathrm{~g} / 100 \mathrm{~g} \mathrm{dw})$ and glucose $(0.92 \mathrm{~g} / 100 \mathrm{~g} \mathrm{dw})$. In $T$. pseudohimalayense,the main free sugars were sorbitol $(17.55 \mathrm{~g} / 100 \mathrm{~g} \mathrm{dw})$ and trehalose $(4.22 \mathrm{~g} / 100 \mathrm{~g} \mathrm{dw})$, followed by glucose $(1.22 \mathrm{~g} / 100 \mathrm{~g}$ $\mathrm{dw}$ ) and inositol $(0.90 \mathrm{~g} / 100 \mathrm{~g} \mathrm{dw})$. T. latisporum showed the highest concentration of trehalose, sorbitol and total sugar; T. subglobosum presented the highest level of inositol; while T. pseudohimalayense was observed with a low trehalose, sorbitol, inositol and total sugar concentration.

Table 2 showed the distribution of saturated fatty acids (SFA), monounsaturated fatty acids (MUFA), and

Table 1 Macronutrients and free sugars composition in dried powder formulations of three Tuber species

\begin{tabular}{lrrr}
\hline & T. latisporum & T. subglobosum & $\begin{array}{l}\text { T.pseudohima- } \\
\text { layense }\end{array}$ \\
\hline Ash $^{d}$ & $8.33 \pm 0.23^{\mathrm{b}}$ & $8.13 \pm 0.23^{\mathrm{b}}$ & $8.77 \pm 0.12^{\mathrm{a}}$ \\
Proteins $^{\mathrm{d}}$ & $14.64 \pm 0.52^{\mathrm{a}}$ & $10.96 \pm 0.35^{\mathrm{b}}$ & $14.28 \pm 0.95^{\mathrm{a}}$ \\
Fat $^{\mathrm{d}}$ & $2.40 \pm 0.03^{\mathrm{b}}$ & $2.23 \pm 0.04^{\mathrm{c}}$ & $2.55 \pm 0.07^{\mathrm{a}}$ \\
Carbohydrates $^{\mathrm{d}}$ & $74.63 \pm 0.39^{\mathrm{b}}$ & $78.68 \pm 0.17^{\mathrm{a}}$ & $74.40 \pm 0.88^{\mathrm{b}}$ \\
Energy $^{\mathrm{e}}$ & $378.64 \pm 0.79^{\mathrm{a}}$ & $378.60 \pm 0.74^{\mathrm{a}}$ & $377.71 \pm 0.70^{\mathrm{a}}$ \\
Glucose $^{\mathrm{d}}$ & $1.25 \pm 0.18^{\mathrm{a}}$ & $0.92 \pm 0.02^{\mathrm{b}}$ & $1.22 \pm 0.05^{\mathrm{a}}$ \\
Trehalose $^{\mathrm{d}}$ & $13.84 \pm 1.02^{\mathrm{a}}$ & $4.41 \pm 0.59^{\mathrm{b}}$ & $4.22 \pm 0.15^{\mathrm{b}}$ \\
Sorbitol $^{\mathrm{d}}$ & $33.82 \pm 3.02^{\mathrm{a}}$ & $22.65 \pm 2.15^{\mathrm{b}}$ & $17.55 \pm 0.36^{\mathrm{c}}$ \\
Inositol $^{\mathrm{d}}$ & $1.18 \pm 0.05^{\mathrm{b}}$ & $2.00 \pm 0.06^{\mathrm{a}}$ & $0.90 \pm 0.01^{\mathrm{c}}$ \\
Total sugars $^{\mathrm{d}}$ & $50.10 \pm 4.22^{\mathrm{a}}$ & $29.98 \pm 2.75^{\mathrm{b}}$ & $23.89 \pm 0.56^{\mathrm{c}}$ \\
\hline
\end{tabular}

$a, b, c$ In each row, the different letters represent significant differences between samples $(\mathrm{p}<0.05) ;{ }^{\mathrm{d}} \%$ or $\mathrm{g} / 100 \mathrm{~g} \mathrm{dw} ;{ }^{\mathrm{e}} \mathrm{kcal} / 100 \mathrm{~g}$ 
Table 2 Distribution of individual fatty acids $(\mathrm{mg})$ in dried powder (100 g) formulations of three Tuber species

\begin{tabular}{|c|c|c|c|}
\hline Fatty acids & T. latisporum & T. subglobosum & T. pseudohimalayense \\
\hline C14:0 & nd & $0.59 \pm 0.03^{\mathrm{a}}$ & nd \\
\hline C15:0 & nd & $0.44 \pm 0.01^{\mathrm{a}}$ & nd \\
\hline C16:0 & $72.36 \pm 0.41^{b}$ & $41.96 \pm 0.36^{c}$ & $80.93 \pm 1.30^{\mathrm{a}}$ \\
\hline C16:1 & $1.06 \pm 0.00^{c}$ & $1.63 \pm 0.01^{b}$ & $3.32 \pm 0.09^{\mathrm{a}}$ \\
\hline $\mathrm{C} 17: 0$ & nd & $0.58 \pm 0.00^{b}$ & $0.72 \pm 0.02^{\mathrm{a}}$ \\
\hline C18:0 & $47.56 \pm 1.75^{\mathrm{a}}$ & $26.06 \pm 0.51^{c}$ & $33.18 \pm 0.48^{b}$ \\
\hline C18:1n9c & $250.97 \pm 0.99^{a}$ & $94.04 \pm 0.96^{c}$ & $219.63 \pm 2.02^{b}$ \\
\hline C18:2n6c & $347.47 \pm 0.07^{b}$ & $246.81 \pm 0.00^{c}$ & $365.24 \pm 0.16^{a}$ \\
\hline C18:3n3 & $9.52 \pm 0.13^{\mathrm{a}}$ & nd & nd \\
\hline C20:0 & $1.01 \pm 0.02^{\mathrm{a}}$ & $0.75 \pm 0.01^{c}$ & $0.86 \pm 0.01^{b}$ \\
\hline C20:1c & $13.15 \pm 0.30^{\mathrm{a}}$ & $0.78 \pm 0.01^{b}$ & $1.00 \pm 0.01^{b}$ \\
\hline$C 20: 2 c$ & $2.99 \pm 0.11^{\mathrm{a}}$ & $1.41 \pm 0.02^{b}$ & $1.41 \pm 0.03^{b}$ \\
\hline$C 20: 4 n 6$ & $0.64 \pm 0.01^{b}$ & $0.63 \pm 0.02^{b}$ & $0.81 \pm 0.02^{\mathrm{a}}$ \\
\hline$C 20: 5 n 3$ & nd & $0.54 \pm 0.02^{\mathrm{a}}$ & $0.53 \pm 0.01^{\mathrm{a}}$ \\
\hline C22:0 & nd & nd & $0.97 \pm 0.01^{\mathrm{a}}$ \\
\hline C24:0 & nd & nd & $0.78 \pm 0.00^{\mathrm{a}}$ \\
\hline SFA $^{1}$ & $121.17 \pm 2.16^{\mathrm{a}}$ & $70.38 \pm 0.58^{c}$ & $117.35 \pm 1.35^{b}$ \\
\hline MUFA $^{f}$ & $265.19 \pm 0.70^{\mathrm{a}}$ & $96.46 \pm 0.96^{c}$ & $223.95 \pm 1.92^{b}$ \\
\hline PUFA $^{f}$ & $360.61 \pm 0.08^{b}$ & $249.39 \pm 0.03^{c}$ & $367.98 \pm 0.19^{a}$ \\
\hline $\mathrm{SFA}^{\mathrm{g}}$ & $16.22 \pm 0.23^{c}$ & $16.91 \pm 0.11^{\mathrm{a}}$ & $16.56 \pm 0.18^{b}$ \\
\hline MUFA' & $35.50 \pm 0.06^{a}$ & $23.17 \pm 0.17^{c}$ & $31.57 \pm 0.23^{b}$ \\
\hline PUFA $^{g}$ & $48.28 \pm 0.18^{c}$ & $59.91 \pm 0.18^{\mathrm{a}}$ & $51.87 \pm 0.11^{\mathrm{b}}$ \\
\hline
\end{tabular}

Myristic acid (C14:0); pentadecanoic acid (C15:0); palmitic acid (C16:0); palmitoleic acid (C16:1); heptadecanoic acid (C17:0); stearic acid (C18:0); oleic acid (C18:1n9c); linoleic acid (C18:2n6c); $a$-linolenic acid (C18:3n3); arachidic acid (C20:0); cis-11-eicosenoic acid (C20:1c); cis-11,14-eicosadienoic acid (C20:2c); arachidonic acid (C20:4n6); eicosapentaenoic acid (C20:5n3); behenic acid (C22:0); lignoceric acid (C24:0)

nd not detected

$a, b, c$ In each row, the different letters represent significant differences between samples $(\mathrm{p}<0.05) ;{ }^{\mathrm{d}} \%$ or $\mathrm{g} / 100 \mathrm{~g} \mathrm{dw} ;{ }^{\mathrm{e}} \mathrm{kcal} / 100 \mathrm{~g} ;{ }^{\mathrm{f}} \mathrm{mg} / 100 \mathrm{~g} \mathrm{dw} ;{ }^{9} \%$ of total FA polyunsaturated fatty acids (PUFA) in the studied lyophilized truffles samples. The results showed that PUFA (from 48.28 to $59.91 \%$ ) were the main group of FA, followed by MUFA (from 23.17 to $35.50 \%$ ) and then SFA (from 16.22 to $16.91 \%$ ). The linoleic acid is a main component of PUFA (linoleic acid levels: from 46.33 to $51.49 \%$ of total FA; PUFA level: from 48.28 to $59.91 \%$ of total FA). Linoleic acid (C18:2n6c), oleic acids (C18:1n9), stearic acids (C18:0) and palmitic acids (C16:0) were the most abundant in the three Tuber truffles. Tuber latisporum showed the highest contents of total FA and UFA, while T. subglobosum had the lowest contents; and in T. pseudohimalayense the contents were close to, but slightly lower than, that of T. latisporum. The content of PUFA (367.98 mg/100 g dw) in T. pseudohimalayense was very close to T. latisporum $(360.61 \mathrm{mg} / 100 \mathrm{~g} \mathrm{dw})$, the lowest was present in T. subglobosum.

\section{Bioactive compounds and antioxidant activity of methanol extracts}

Table 3 presents phenols, flavonoids, ascorbic acid, $\beta$-carotenoid, lycopene and phenolic acids concentrations contained in methanol extract of the three Tuber samples. Phenols, flavonoids, $\beta$-carotenoid and lycopene were the major bioactive components in these samples. Extraction of $T$. pseudohimalayense showed a highest content of phenols (735.01 mg of GAE/100 g extract), whereas that of T. subglobosum and T. latisporum were lower and close to each other $(450.2 \mathrm{mg}$ of GAE/100 g extract) and $446.6 \mathrm{mg}$ of $\mathrm{GAE} / 100 \mathrm{~g}$ extract, respectively). Extraction of T. subglobosum showed a highest content of flavonoids (1.355 g of rutin/100 g extract), followed by $T$. latisporum $(900.2 \mathrm{mg}$ of rutin/100 $\mathrm{g}$

Table 3 Content of antioxidant compounds in the methanol extract of freeze-dried powder of three Tuber species

\begin{tabular}{|c|c|c|c|}
\hline & T. latisporum & T. subglobosum & T. pseudohimalayense \\
\hline Total phenols ${ }^{h}$ & $446.60 \pm 3.8^{b}$ & $450.20 \pm 3.4^{b}$ & $735.01 \pm 2.5^{\mathrm{a}}$ \\
\hline Total flavonoids ${ }^{i}$ & $900.22 \pm 14.72^{b}$ & $1355.43 \pm 18.01^{\mathrm{a}}$ & $611.26 \pm 7.40^{c}$ \\
\hline Vitamin $C^{\mathrm{j}}$ & $4.63 \pm 0.01^{\mathrm{a}}$ & $4.61 \pm 0.01^{\mathrm{ab}}$ & $4.59 \pm 0.02^{\mathrm{b}}$ \\
\hline Total carotenoids ${ }^{k}$ & $170.63 \pm 3.06^{b}$ & $144.33 \pm 0.87^{c}$ & $271.33 \pm 0.66^{a}$ \\
\hline Lycopene $^{j}$ & $236.03 \pm 0.80^{b}$ & $151.62 \pm 0.32^{c}$ & $355.18 \pm 0.46^{\mathrm{a}}$ \\
\hline Gallic & nd & $40.87 \pm 0.42^{b}$ & $39.83 \pm 0.46^{\mathrm{a}}$ \\
\hline 4-Hydroxybenzoic ${ }^{j}$ & $24.84 \pm 0.05^{\mathrm{a}}$ & nd & $21.93 \pm 0.63^{b}$ \\
\hline 3,4-Dihydroxybenzaldehyde & $62.71 \pm 0.11^{a}$ & nd & nd \\
\hline Homogentisic acidj & $61.03 \pm 0.35^{\mathrm{a}}$ & $23.03 \pm 015^{c}$ & $64.13 \pm 0.25^{b}$ \\
\hline p-Coumaric acidj & nd & nd & nd \\
\hline o-Coumaric acidj & nd & nd & nd \\
\hline
\end{tabular}

nd not detected

a,b,c In each row, the different letters represent significant differences between samples $(\mathrm{p}<0.05) ;{ }^{\mathrm{d}} \%$ or $\mathrm{g} / 100 \mathrm{~g} \mathrm{dw} ;{ }^{\mathrm{e}} \mathrm{kcal} / 100 \mathrm{~g} ;{ }^{\mathrm{f}} \mathrm{mg} / 100 \mathrm{~g} \mathrm{dw} ;{ }^{\mathrm{g}} \%$ of total FA; ${ }^{\mathrm{h}} \mathrm{mg}$ of GAE/100 g extract; ${ }^{i} \mathrm{mg}$ of Rutin/100 $\mathrm{g}$ extract; ${ }^{\mathrm{j}} \mathrm{g} / 100 \mathrm{~g}$ extract; ${ }^{\mathrm{k}} \mathrm{mg}$ of $\beta$-carotene/100 $\mathrm{g}$ extract 
extract) and then T. pseudohimalayense (611.3 $\mathrm{mg}$ of rutin/100 g extract). Extraction of T. pseudohimalayense revealed a high content in $\beta$-carotenoid and lycopene $(271.3 \mathrm{mg}$ of $\beta$-carotene/100 g extract and $355.2 \mathrm{mg} / 100 \mathrm{~g}$ extract, respectively), followed by $T$. latisporum (170.6 mg of $\beta$-carotene/100 g extract and $236.0 \mathrm{mg} / 100 \mathrm{~g}$ extract, respectively) and then $T$. subglobosum (144.3 $\mathrm{mg}$ of $\beta$-carotene/100 g extract and $151.62 \mathrm{mg} / 100 \mathrm{~g}$ extract, respectively). All three Tuber samples showed a similar content of ascorbic acid, within the range of 4.59-4.63 g/100 g extract. Moreover, four phenolic compounds, gallic acid, 4-hydroxybenzoic acid, 3,4-dihydroxybenzaldehyde and homogentisic acid were identified in these truffles (Table 3). Of them, homogentisic acid was detected in all samples, with a high concentration in T. latisporum (61.03 mg/100 g extract) and T. pseudohimalayense $(64.13 \mathrm{mg} / 100 \mathrm{~g}$ extract) and a moderate level in $T$. subglobosum ( $23.03 \mathrm{mg} / 100 \mathrm{~g}$ extract); 3,4-dihydroxybenzaldehyde was just found in T. latisporum $(62.71 \mathrm{mg} / 100 \mathrm{~g}$ extract); gallic acid was detected in T. subglobosum (40.87 mg/100 g extract) and T. pseudohimalayense (39.83 mg/100 g extract); 4-hydroxybenzoic acid was found in T. latisporum ( $24.84 \mathrm{mg} / 100 \mathrm{~g}$ extract) and T. pseudohimalayense (21.93 mg/100 g extract); gallic acid and 4-hydroxybenzoic acid were all not detected (<LOD) in T. latisporum and T. subglobosum.

The antioxidant activity of the extracts obtained from our truffle powder formulations was evaluated by different in vitro assays (Table 4). Tuber latisporum showed the most efficient reducing power measured by ferrous ion-chelating assay and ferricyanide/prussian blue assay, which is compatible to the variety and content of phenolic acids. Ferrous ion-chelating activity of $T$. subglobosum was higher than that of T. pseudohimalayense. Ferricyanide/Prussian blue assay of our three truffles showed a general reducing power $\left(\mathrm{EC}_{50}\right.$ : 12.95 $20.02 \mathrm{mg} / \mathrm{mL}$ ). Tuber pseudohimalayense was the most efficient species concerning radical scavenging activity measured by DPPH scavenging activity and hydroxyl radical-scavenging assay. T. latisporum presented lower radical scavenging property than $T$. pseudohimalayense, which is compatible to its lower total phenols, $\beta$-carotenoid and lycopene content (Table 3).

\section{Discussion}

Although many edible mushrooms, including truffles, are the subject of scientific studies that confirm their benefits, there are many species that are still poorly explored. In this study, the powder formulations of the three Tuber species revealed the presence of essential nutrients such as proteins, carbohydrates and UFA. They present low fat content and high content of protein as well as unsaturated fatty acid, which is beneficial to human health.

Of our three truffles, the white truffle $T$. latisporum showed the highest content of protein (14.64\%), followed by the red truffle T. pseudohimalayense (14.28\%), they are higher than the value reported for black truffles $T$. aestivum (11-12.9\%) and T. melanosporum (7.5-8.7\%) by Saltarelli et al. (2008); the protein of pale yellow truffle $T$. subglobosum (10.96\%) was higher than that of black truffles T. melanosporum (7.5-8.7\%). Saltarelli et al. (2008) evidenced white truffle $T$. magnatum from Italy are rich source of proteins (20.5-24\%). With regard to desert truffle, Sawaya et al. (1985) compared the compositional difference amongst three Saudi Arabian truffles including two black desert truffles Gibaah and Kholeissi (both are Terfezia claveryi according to Hussain and Al-Ruqaie 1999) and one white truffle Tirmania nivea (Zubaidi). They found these truffles' protein contents ranged from 19.59 to $27.18 \%$, and the white truffle $T$. nivea had the highest protein content. These remind us that white truffles probably contain more protein.

Beara et al. (2014) determinate gallic acid of $0.2 \mu \mathrm{g} / \mathrm{g}$ $\mathrm{dw}$ in the methanol extract of T. magnatum from Serbia, which was remarkably lower than that in T. subglobosum $(9.11 \mu \mathrm{g} / \mathrm{g} \mathrm{dw})$ and T. pseudohimalayense $(10.16 \mu \mathrm{g} / \mathrm{g} \mathrm{dw})$ in this study. Phenolic compounds in T. melanosporum, $T$. aestivum and T. indicum from Soria (Spain) were

Table 4 Antioxidant activity of the methanol extracts obtained from dried powder formulations of three Tuber species from China

\begin{tabular}{|c|c|c|c|c|}
\hline \multirow[t]{2}{*}{ Antioxidant properties } & \multirow[t]{2}{*}{ Assay } & \multicolumn{3}{|c|}{$\mathrm{EC}_{50}$ value $(\mathrm{mg} / \mathrm{mL})$} \\
\hline & & T. latisporum & T. subglobosum & T.pseudohimalayense \\
\hline \multirow[t]{2}{*}{ Reducing power } & Ferrous ion-chelating & $0.82 \pm 0.07^{c}$ & $1.50 \pm 0.08^{b}$ & $1.92 \pm 0.13^{\mathrm{a}}$ \\
\hline & Ferricyanide/Prussian blue & $12.95 \pm 0.03^{c}$ & $13.69 \pm 0.12^{b}$ & $20.02 \pm 0.10^{\mathrm{a}}$ \\
\hline \multirow[t]{2}{*}{ Radical scavenging } & $\mathrm{DPPH}$ & $6.94 \pm 0.15^{b}$ & $7.87 \pm 0.15^{\mathrm{a}}$ & $6.03 \pm 0.26^{c}$ \\
\hline & Hydroxyl radical & $1.29 \pm 0.03^{\mathrm{a}}$ & $1.32 \pm 0.04^{\mathrm{a}}$ & $1.11 \pm 0.04^{b}$ \\
\hline
\end{tabular}

The results are presented in $\mathrm{EC}_{50}$ values, meaning that higher values correspond to lower reducing power, radical scavenging activity. $\mathrm{EC}_{50}$ is the concentration of the extract that corresponds to $50 \%$ of antioxidant activity for the ferrous ion-chelating, DPPH, hydroxy, and or 0.5 of absorbance for the ferricyanide/Prussian blue assays $a, b, c$ In each row, the different letters represent significant differences between samples $(p<0.05)$ 
analysed by Villares et al. (2012). Gallic acid was found in T. aestivum $(63.65 \mu \mathrm{g} / \mathrm{g})$ and T. indicum $(61.54 \mu \mathrm{g} / \mathrm{g})$, which were significantly lower than in $T$. subglobosum (40.87 mg/100 g extract) and T. pseudohimalayense (39.83 mg/100 g extract).

Linoleic acid (C18:2n6c), oleic acids (C18:1n-9), stearic acids $(\mathrm{C} 18: 0)$ and palmitic acids (C16:0) were the most abundant in three Tuber truffles. Previous studies on FA of Tuber species, including T. texense (Beuchat et al. 1993), T. melanosporum (Harki et al. 2006), T. magnatum (Angelini et al. 2015), T. aestivum (Tang et al. 2011; Angelini et al. 2015), T. indicum, T. himalayense, and T. borchii (Tang et al. 2011), also showed that the major ingredients of FA were UFA, particularly include linoleic acid and oleic acid. Noteworthily, Tang et al. (2011) first discovered arachidonic, eicosapentaenoic (EPA), docosahexaenoic (DHA), and $\gamma$-linolenic acids in Tuber species, and two of them, arachidonic and EPA, were identified in this study. Furthermore, $\alpha$-linolenic acid (ALA), as the precursor of EPA and DHA, also appeared in T. latisporum.

The three truffles all showed high antioxidant activity, especially T. latisporum and T. pseudohimalayense, which were also richer in phenolic compounds than $T$. subglobosum. Compared with our three truffles, $T$. indicum $\left(\mathrm{EC}_{50}>30 \mathrm{mg} / \mathrm{mL}\right)$ with a lower levels of total phenols (2.62 mg GAE/g) and flavonoids (1.97 mg Rutin/g extract) had a lower reducing power and a lower hydroxyl radical scavenging activity $\left(\mathrm{EC}_{50}: 25.6 \mathrm{mg} / \mathrm{mL}\right.$ ) (Guo et al. 2011). However, T. indicum could be good at scavenging DPPH radical $\left(E_{50}: 1.61 \mathrm{mg} / \mathrm{mL}\right)$, whereas our three truffles more tend to scavenge hydroxyl radical $\left(\mathrm{EC}_{50}\right.$ : $1.11-1.32 \mathrm{mg} / \mathrm{mL}$ ) (Guo et al. 2011).

There is a relationship between antioxidant activity and the concentrations of total phenol, total flavonoid and phenolic acids, but not a linear relationship. The antioxidant action may be raised by other substances such as tocopherols and $\beta$-carotene (Cheung et al. 2003). We need more effort to know what kind of material is played a key role in the reaction. All in all, the studied truffle power formulations might be useful as nutraceuticals and antioxidant-rich supplements.

\section{Abbreviations \\ GC-MS: gas chromatography-mass spectrometer; HPLC: high-performance liquid chromatography; ME: methanol extract; DAD: diode array detector; PUFA: polyunsaturated fatty acids; MUFA: monounsaturated fatty acids; SFA: saturated fatty acids; FA: fatty acids; UFA: unsaturated fatty acids.}

\section{Authors' contributions}

$L F$ and $X Y$ designed whole experiment; $X S$ and $Y W$ helped to carry the experiment; XS and XY contributed data analysis. XY wrote the article and LF helped on the paperwork. All authors read and approved the final manuscript.

\section{Acknowledgements}

Not applicable.

\section{Competing interests}

The authors declare that they have no competing interests.

Availability of data and materials

All datasets on which the conclusions of the manuscript rely are presented in the main paper.

\section{Funding}

The study was funded by the National Natural Science Foundation of China (No. 31270058) and the Beijing Natural Science Foundation (No. 5172003).

\section{Publisher's Note}

Springer Nature remains neutral with regard to jurisdictional claims in published maps and institutional affiliations.

Received: 12 April 2017 Accepted: 16 June 2017

Published online: 26 June 2017

\section{References}

Angelini P, Tirillini B, Properzi A, Rol C, Venanzoni R (2015) Identification and bioactivity of the growth inhibitors in spp. methanolic extracts. Plant Biosyst 2015(2):21

Barros L, Ferreira MJ, Queirós B, Ferreira IC, Baptista P (2007) Total phenols, ascorbic acid, $\beta$-carotene and lycopene in Portuguese wild edible mushrooms and their antioxidant activities. Food Chem 103:413-419

Beara IN, Lesjak MM, Četojević-Simin DD, Marjanović ZS, Ristić JD, Mrkonjić ZO, Mimica-Dukić NM (2014) Phenolic profile, antioxidant, anti-inflammatory and cytotoxic activities of black (Tuber aestivum Vittad.) and white (Tuber magnatum Pico) truffles. Food Chem 165:460-466

Beuchat LR, Brenneman TB, Dove CR (1993) Composition of the pecan truffle (Tuber texense). Food Chem 46:189-192

Bokhary HA, Sarwat P (1993) Chemical composition of desert truffles Terfezia claveryi. J Food Compos Anal 6(3):285-293

Carneiro AA, Ferreira IC, Dueñas M, Barros L, da Silva R, Gomes E, SantosBuelga C (2013) Chemical composition and antioxidant activity of dried powder formulations of Agaricus blazei and Lentinus edodes. Food Chem 138:2168-2173

Cheung LM, Cheung PCK, Ooi VCE (2003) Antioxidant activity and total phenolics of edible mushroom extracts. Food Chem 81:249-255

Culleré L, Ferreira V, Chevret B, Venturini E, Sánchez-Gimeno AC, Blanco D (2010) Characterisation of aroma active compounds in black truffles (Tuber melanosporum) and summer truffles (Tuber aestivum) by gas chromatography-olfactometry. Food Chem 122:300-306

Dubost NJ, Ou B, Beelman RB (2007) Quantification of polyphenols and ergothioneine in cultivated mushroom and correlation to total antioxidant capacity. Food Chem 105(2):727-735

Dundar A, Yesil OF, Acay H, Okumus V, Ozdemir S, Yildiz A (2012) Antioxidant properties, chemical composition and nutritional value of Terfezia boudieri (Chatin) from Turkey. Food Sci Technol Int 18(4):317-328

Gao JM, Liu HL, Liu JK (2001a) A novel sterol from Chinese truffles Tuber indicum. Steroids 66:771-775

Gao JM, Wang CY, Zhang AL, Liu JK (2001 b) A new trihydroxy fatty acid from the ascomycete. Chinese truffle Tuber indicum. Lipids 36(12):1365-1370

Guo T, Wei L, Sun J, Hou CL, Fan L (2011) Antioxidant activities of extract and fractions from Tuber indicum Cooke \& Massee. Food Chem 127:1634-1640

Hall IR, Yun W, Amicucci A (2003) Cultivation of edible ectomycorrhizal mushrooms. Trends Biotechnol 21:433-438

Hamza A, Zouari N, Zouari S, Jdir H, Zaidi S, Gtari M, Neffti M (2016) Nutraceutical potential, antioxidant and antibacterial activities of Terfezia boudieri Chatin, a wild edible desert truffle from Tunisia arid zone. Arabian J Chem 9(3):383-389

Harki E, Bouya D, Dargent R (2006) Maturation-associated alterations of the biochemical characteristics of the black truffle Tuber melanosporum Vitt. Food Chem 99(2):394-400

Hussain G, Alruqaie IM (1999) Occurrence, chemical composition, and nutritional value of truffles: an overview. PJBS 2(2):510-514 
Kehrer JP (1993) Free radicals as mediators of tissue injury and disease. Crit Rev Toxicol 23:21-48

Klein BP, Perry AK (1982) Ascorbic acid and vitamin A activity in selected vegetables from different geographical areas of the United States. J Food Sci 47(941-945):948

Lee J, Koo N, Min DB (2004) Reactive oxygen species, aging, and antioxidative nutraceuticals. Compr Rev Food Sci Food Saf 3:21-33

Murcia MA, Martinez-Tome M, Jimenez A, Vera A, Honrubia M, Parras P (2002) Antioxidant activity of edible fungi (truffles and mushrooms): losses during industrial processing. J Food Prot 65:1614-1622

Saltarelli R, Ceccaroli P, Cesari P, Barbieri E, Stocchi V (2008) Effect of storage on biochemical and microbiological parameters of edible truffle species. Food Chem 109:8-16

Sawaya WN, Al-Shalhat A, Al-Soair A, Al-Mahammad M (1985) Chemical composition and nutritional values of truffles of Saudi Arabia. J Food Sci 50:450-453
Stojković D, Reis FS, Ferreira IC, Barros L, Glamočlija J, Ćirić A, Nikolić M, Stević T, Giveli A, Soković M (2013) Tirmania pinoyi: chemical composition, in vitro antioxidant and antibacterial activities and in situ control of Staphylococcus aureus in chicken soup. Food Res Int 53:56-62

Tang Y, Li YY, Li HM, Wan DJ, Tang YJ (2011) Comparison of lipid content and fatty acid composition between tuber fermentation mycelia and natural fruiting bodies. J Agric Food Chem 59(9):4736-4742

Tang Y, Li HM, Tang YJ (2012) Comparison of sterol composition between Tuber fermentation mycelia and natural fruiting bodies. Food Chem 132:1207-1213

Villares A, García-Lafuente A, Guillamón E, Ramos À (2012) Identification and quantification of ergosterol and phenolic compounds occurring in Tuber spp. truffles. J Food Compos Anal 26:177-182

Wang S, Marcone MF (2011) The biochemistry and biological properties of the world's most expensive underground edible mushroom: truffles. Food Res Int 44:2567-2581

\section{Submit your manuscript to a SpringerOpen ${ }^{\odot}$ journal and benefit from:}

- Convenient online submission

- Rigorous peer review

- Open access: articles freely available online

- High visibility within the field

- Retaining the copyright to your article

Submit your next manuscript at $\boldsymbol{\nabla}$ springeropen.com 